\title{
Particulate Size of Microalgal Biomass Affects Hydrolysate Properties and Bioethanol Concentration
}

\author{
Razif Harun, ${ }^{1,2}$ Michael K. Danquah, ${ }^{3}$ and Selvakumar Thiruvenkadam ${ }^{2}$ \\ ${ }^{1}$ Department of Chemical Engineering, Monash University, Clayton, VIC 3800, Australia \\ ${ }^{2}$ Department of Chemical and Environmental Engineering, Universiti Putra Malaysia, 43400 Serdang, Malaysia \\ ${ }^{3}$ Department of Chemical and Petroleum Engineering, Curtin University of Technology, 98009 Sarawak, Malaysia
}

Correspondence should be addressed to Razif Harun; mh_razif@upm.edu.my

Received 28 February 2014; Revised 3 May 2014; Accepted 6 May 2014; Published 29 May 2014

Academic Editor: Rajeev Kumar

Copyright (C) 2014 Razif Harun et al. This is an open access article distributed under the Creative Commons Attribution License, which permits unrestricted use, distribution, and reproduction in any medium, provided the original work is properly cited.

\begin{abstract}
Effective optimization of microalgae-to-bioethanol process systems hinges on an in-depth characterization of key process parameters relevant to the overall bioprocess engineering. One of the such important variables is the biomass particle size distribution and the effects on saccharification levels and bioethanol titres. This study examined the effects of three different microalgal biomass particle size ranges, $35 \mu \mathrm{m} \leq x \leq 90 \mu \mathrm{m}, 125 \mu \mathrm{m} \leq x \leq 180 \mu \mathrm{m}$, and $295 \mu \mathrm{m} \leq x \leq 425 \mu \mathrm{m}$, on the degree of enzymatic hydrolysis and bioethanol production. Two scenarios were investigated: single enzyme hydrolysis (cellulase) and double enzyme hydrolysis (cellulase and cellobiase). The glucose yield from biomass in the smallest particle size range $(35 \mu \mathrm{m} \leq x \leq 90 \mu \mathrm{m})$ was the highest, $134.73 \mathrm{mg}$ glucose/g algae, while the yield from biomass in the larger particle size range $(295 \mu \mathrm{m} \leq x \leq 425 \mu \mathrm{m})$ was $75.45 \mathrm{mg}$ glucose/g algae. A similar trend was observed for bioethanol yield, with the highest yield of $0.47 \mathrm{~g} \mathrm{EtOH} / \mathrm{g}$ glucose obtained from biomass in the smallest particle size range. The results have shown that the microalgal biomass particle size has a significant effect on enzymatic hydrolysis and bioethanol yield.
\end{abstract}

\section{Introduction}

The utilization of microalgae to produce a variety of products such as fine organic chemicals, food, animal feed, and food supplements have been discovered in the past [1-3]. Current interest has been on the development of biofuels, such as bioethanol, from microalgae as a nonedible feedstock. Aside from its renewable and sustainable benefits, the high carbohydrate composition of microalgal biomass can be converted to fermentable sugars for microbial conversion to bioethanol $[4,5]$. One of such biomass saccharification methods is via enzymatic hydrolysis.

Enzymatic hydrolysis is a well-established process and provides mild operating conditions, high sugar yields, high selectivity, and minimal by-products formation [6,7], hence a more preferred method of hydrolyzing fermentation substrates. However, process conditions and parameters during enzymatic hydrolysis require detailed optimization for maximum product conversion. One of the important parameters that influence the effectiveness of enzymatic hydrolysis is biomass particle size. Fundamentally, smaller particle size biomass presents a large specific surface area, thus increasing the contact areas between the enzymes and the interparticle bonding of the material during the hydrolysis process [8].

Previous attention has been focused on the effect of particle size on enzymatic hydrolysis of either cellulosic (such as cotton, plant, and fibers) or lignocellulosic biomass (such as corn, sugarcane, and wheat). Pedersen and Meyer [9] reported that smaller biomass particle size $(53-149 \mu \mathrm{m})$ increased glucose release up to $90 \%$ after 24 h hydrolysis of wheat straw biomass. The finding was in accordance with those reported by Dasari and Eric Berson [10] and Carvalho et al. [11] who used sawdust and lemon, respectively, as hydrolysis substrates. Biomass particulate size reduction also results in enhancing the hydrolysis rate $[10,12]$. This can be explained by the easy access to enzyme active sites by smaller biomass particles. Contrary to this, Ballesteros et al. $[13,14]$ have reported that larger particle size biomass significantly 
increases hydrolysis rates and sugar recoveries (particularly glucose) compared to smaller particle size biomass. These conflicting views call for further studies on the characteristic effects of biomass particle size on the degree and effectiveness of enzymatic hydrolysis. To the best of our knowledge, no similar work has been performed on the carbohydrates of microalgae biomass and the concomitant effect on bioethanol yields. Therefore, this study aims to investigate the effect of particle size on enzymatic hydrolysis of microalgal biomass. The glucose yields and the physical properties of the substrate during the hydrolysis process are examined and discussed. Also, the kinetic investigation of enzyme hydrolysis and the effects on glucose and bioethanol yields are presented.

\section{Materials and Methods}

2.1. Substrate Preparation. Culture samples of Chlorococcum infusionum obtained from Bio-fuels Pty Ltd (Victoria, Australia) were centrifuged (Heraeus Multifuge 3 S-R, Germany) at $4500 \times \mathrm{g}$ for $10 \mathrm{mins}$ and the supernatant was discarded. The microalgal cake was dried in a laboratory oven at $60^{\circ} \mathrm{C}$ for $24 \mathrm{~h}$ (Model 400, Memmert, Germany). The dried biomass was pulverized for $1 \mathrm{~min}$ using a hammer mill (N.V Tema, Germany). The different particle sizes were separated by passing the milled sample through a series of cascaded stainless steel sieves (until the desired biomass sizes were partitioned in the following ranges: $35 \mu \mathrm{m} \leq x \leq 90 \mu \mathrm{m}$, $125 \mu \mathrm{m} \leq x \leq 180 \mu \mathrm{m}$, and $295 \mu \mathrm{m} \leq x \leq 425 \mu \mathrm{m})$. The samples were stored at room temperature before further analysis.

2.2. Enzyme Activity. The enzymes used in this study were cellulase from Trichoderma reesei (ATCC 26921) and cellobiase from Aspergillus niger (Novozyme 188), purchased from Sigma Aldrich, Australia. The activity of cellulase measured at 1.0 units $/ \mathrm{mg}$ solid means that one unit of cellulase liberates $1.0 \mu \mathrm{mol}$ of glucose from cellulose in $1 \mathrm{~h}$ at $\mathrm{pH}$ 5.0. The cellobiase activity was determined as 250 units/mg.

2.3. Enzymatic Hydrolysis. Varying quantities of microalgal biomass in powder form (0.2-1.0 g) within three different particle size ranges $35 \mu \mathrm{m} \leq x \leq 90 \mu \mathrm{m}, 125 \mu \mathrm{m} \leq x \leq 180 \mu \mathrm{m}$, and $295 \mu \mathrm{m} \leq x \leq 425 \mu \mathrm{m}$ were loaded with a constant cellulase mass of $20 \mathrm{mg}$ and a cellobiase volume of $1.0 \mathrm{~mL}$. The samples were hydrolysed in shake flasks with $10 \mathrm{mM}$ of $100 \mathrm{~mL}$ sodium acetate buffer at $\mathrm{pH} 4.8$ and were placed in an incubator (LH Fermentation Ltd., Buckinghamshire, England) at $40^{\circ} \mathrm{C}$ for $48 \mathrm{~h}$ with $200 \mathrm{RPM}$ agitation. Samples were taken at $5 \mathrm{~h}$ intervals and the enzymatic hydrolysis process was halted by heating the hydrolysate to $\sim 90^{\circ} \mathrm{C}$ for $10 \mathrm{~min}$. The samples were then cooled to room temperature and stored in a freezer at $-75^{\circ} \mathrm{C}$ (Ultraflow freezer, Plymouth, USA) for further analysis.

2.4. Bioethanol Production. Saccharomyces cerevisiae, purchased from Lalvin, Winequip Products Pty Ltd. (Victoria, Australia), was used in the microbial fermentation process for bioethanol production. The culture was prepared by dissolving $5.0 \mathrm{~g}$ of dry yeast powder in $50 \mathrm{~mL}$ sterile warm water $\left(\sim 40^{\circ} \mathrm{C}\right)$ and the $\mathrm{pH}$ was adjusted to 7 by $1 \mathrm{M} \mathrm{NaOH}$ addition. The yeast was cultured in YDP medium with composition in $\mathrm{g} / \mathrm{L}$ given as follows: $10 \mathrm{~g}$ yeast extract, $20 \mathrm{~g}$ peptone, and $20 \mathrm{~g}$ glucose. The yeast was harvested after $24 \mathrm{~h}$ and washed to eliminate the sugars then transferred into $500 \mathrm{~mL}$ Erlenmeyer flask containing $100 \mathrm{~mL}$ of the sugar-containing liquid medium obtained after the hydrolysis process. The flasks were tightly sealed and nitrogen gas was bubbled through to create an oxygen-free environment for bioethanol production. The flasks were incubated at $30^{\circ} \mathrm{C}$ under $200 \mathrm{RPM}$ shaking. The $\mathrm{pH}$ was maintained at 7 by adding $1 \mathrm{M} \mathrm{NaOH}$ solution. The fermentation continued for $50 \mathrm{~h}$ and samples for analysis were taken after every $4 \mathrm{~h}$.

2.5. Chemical Analysis. The biomass was pretreated using a sonicator to break down the cell walls. Phenol-sulphuric acid method was used to quantify the total carbohydrate in the biomass. Note that Table 1 is a presaccharification data, presenting the existence of different carbohydrate forms entrapped in the microalgae system. Microalgal biomass and the hydrolysate compositions were analyzed by HPLC using a $250 \mathrm{~mm} \times 4.6 \mathrm{~mm}$ Prevail Carbohydrate ES Column. The HPLC system consists of the following accessory instruments: a detector (ELSD, Alltech 3300), quaternary gradient pump (Model 726, Alltech), degasser (Model 591500M Elite degassing system, Alltech), autosampler (Model 570, Alltech), and system controller (Model 726300M, Alltech). The mobile phase was a mixture of acetonitrile and water $(85: 15)$ and the operating flow rate was $1 \mathrm{~mL} / \mathrm{min}$. $30 \mu \mathrm{L}$ sample was injected at $50^{\circ} \mathrm{C}$. The sample was filtered through a $13 \mathrm{~mm}$ membrane filter prior to injection. The sugar concentrations were evaluated using a calibration curve generated from HPLC-grade sugars.

The ethanol concentration was analyzed using gas chromatography (GC) (Model 7890A, Agilent, USA). The GC unit consists of an autosampler, flame ion detector (FID), and HP-FFAP column $(50 \mathrm{~m} \times 0.20 \mathrm{~mm} \times 0.33 \mu \mathrm{m})$. The injector, detector, and oven temperatures were maintained at $150^{\circ} \mathrm{C}, 200^{\circ} \mathrm{C}$, and $120^{\circ} \mathrm{C}$, respectively. Nitrogen gas was used as the carrier gas. The bioethanol concentration was quantified using a calibration curve prepared by injecting different concentrations of a standard ethanol $(0.1-10 \% \mathrm{v} / \mathrm{v})$.

2.6. Fourier Transform Infrared Spectroscopy (FTIR). The polymorphs of the resulting hydrolysate from the hydrolysis process were determined by FTIR. FTIR spectra of hydrolysed samples were recorded on a Nicolet 6700 FTIR (Fischer Scientific, Australia) equipped with Thermo Scientific iD3 ATR accessory (Fischer Scientific, Australia), and the spectra were run and processed with OMNIC software (Version 7.0 ThermoNicolet). The dried hydrolysis samples were loaded on the sample holder and the spectrum was recorded at an average of 32 scans with a spectral resolution of $4 \mathrm{~cm}^{-1}$ from 400 to $4000 \mathrm{~cm}^{-1}$. Sample spectra were recorded as absorbance values at each data point in triplicates. 
TABLE 1: Biomass composition of the microalgal species.

\begin{tabular}{lc}
\hline Component & Composition $(\% \mathrm{w} / \mathrm{w})$ \\
\hline Total carbohydrate & 32.52 \\
Xylose & 9.54 \\
Mannose & 4.87 \\
Glucose & 15.22 \\
Galactose & 2.89 \\
Starch & 11.32 \\
Others $^{*}$ & 56.16 \\
\hline
\end{tabular}

${ }^{*}$ Lipids, protein, and ash.

2.7. Viscosity Measurement. The hydrolysate viscosities were determined using a modular advanced rheometer system (Haake Mars, Thermo Electron Corp., Germany). The system is equipped with a stainless steel measuring plate (MP 660, $60 \mathrm{~mm})$ and a rotor $(\mathrm{PP} 60 \mathrm{H}, 60 \mathrm{~mm})$. The temperature was set to $30^{\circ} \mathrm{C}$, the frequency was maintained at $1.5 \mathrm{~Hz}$, and the gap between the parallel plates was kept at $1 \mathrm{~mm}$. The hydrolysed samples were measured for $5 \mathrm{~min}$ at different shear rates ranging from 50 to $500 \mathrm{~s}^{-1}$.

\section{Results and Discussion}

3.1. Substrate Carbohydrate Composition. According to Table 1, carbohydrate constitutes up to $32 \%$ of the dry weight of $C$. infusionum biomass with the major fermentable sugar component being glucose (15.2\%), followed by xylose $(9.5 \%)$, mannose $(4.9 \%)$, and galactose $(2.9 \%)$. This strain also contains starch at $11.3 \%$ dry weight. The total carbohydrates present in the biomass could be made available for bioethanol production under optimal saccharification and microbial fermentation conditions. The remaining biomass composition could represent lipids, protein, and ash that is available in microalgal strain. Unlike both red and brown algae, the cell wall of most green algae has high cellulose content, ranging up to $70 \%$ of the dry weight $[15,16]$. The composition of the carbohydrate content in the unicellular microalgal specie per unit mass does not vary greatly among fractions of different particle size. For intact microalgae cells, the carbohydrates are well distributed within the cell membrane and this gives a uniform carbohydrate composition in the membrane.

3.2. FTIR Analysis. The spectra of hydrolyzed biomass with different particle sizes were examined using FTIR techniques and the results are shown in Figure 1. Two types of hydrolysates were compared in this study: single enzyme hydrolysate with only cellulase and double enzyme hydrolysate with both cellulase and cellobiase. These two scenarios are denoted by Case 1 and Case 2, respectively. The FTIR spectra represent samples taken at the end of the hydrolysis process. The spectrum of nonpretreated powdered microalgae within the size range of $295 \mu \mathrm{m} \leq x \leq 425$ $\mu \mathrm{m}$ was analyzed for comparison. According to Murdock and Wetzel [17], the reference absorption peaks for major

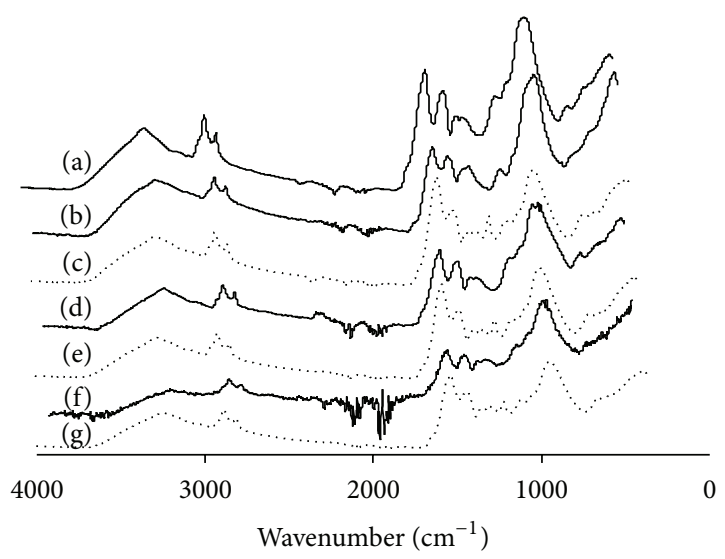

FIGURE 1: FTIR spectra for microalgal biomass with different particle sizes under different Cases. (a) Nonpretreated microalgal biomass (original powdered sample); Case 1 (cellulase only): (b) $35 \mu \mathrm{m} \leq x \leq$ $90 \mu \mathrm{m}$, (d) $125 \mu \mathrm{m} \leq x \leq 180 \mu \mathrm{m}$, and (f) $295 \mu \mathrm{m} \leq x \leq 425 \mu \mathrm{m}$; Case 2 (cellulase + cellobiase): (c) $35 \mu \mathrm{m} \leq x \leq 90 \mu \mathrm{m}$, (e) $125 \mu \mathrm{m} \leq x \leq$ $180 \mu \mathrm{m}$, and (g) $295 \mu \mathrm{m} \leq x \leq 425 \mu \mathrm{m}$.

microalgal compositions are $\sim 1100-900 \mathrm{~cm}^{-1}$ for polysaccharides (cellulose and starch), $\sim 2970-2850 \mathrm{~cm}^{-1}$ for lipids, and $1750-1500 \mathrm{~cm}^{-1}$ for proteins and carboxylic groups. Since we wish to convert complex carbohydrates in the biomass to produce fermentable sugars for bioethanol production, only polysaccharide peaks are of interest. The microalgal biomass used in this study showed a relatively high amount of polysaccharides since a strong absorption peak was recorded around $1100 \mathrm{~cm}^{-1}$ to $1000 \mathrm{~cm}^{-1}$ in the powdered microalgal sample as summarized in Figure 1. It was observed that the degree of polysaccharides absorption decreased as the biomass particle size decreased. This indicates that more polysaccharides were converted to fermentable sugars in the case of biomass with smaller particle size during the hydrolysis process. Based on the individual spectrum, sugar conversions were calculated by referring to the peak heights of nonpretreated samples. The hydrolysis of cellulose with the addition of cellobiase (Case 2) generated hydrolysis conversion of 90,78 , and $64 \%$ of the biomass in the particle size ranges $35 \mu \mathrm{m} \leq$ $x \leq 90 \mu \mathrm{m}, 125 \mu \mathrm{m} \leq x \leq 180 \mu \mathrm{m}$, and $295 \mu \mathrm{m} \leq$ $x \leq 425 \mu \mathrm{m}$, respectively. A lower degree of hydrolysis was observed without cellobiase addition (Case 1) of 41, 29, and $18 \%$ for biomass in the particle size ranges $35 \mu \mathrm{m} \leq$ $x \leq 90 \mu \mathrm{m}, 125 \mu \mathrm{m} \leq x \leq 180 \mu \mathrm{m}$, and $295 \mu \mathrm{m} \leq x \leq$ $425 \mu \mathrm{m}$, respectively. Cellulase contains cellobiohydrolases, endoglucanases, and $\beta$-glucosidase that function to efficiently hydrolyse cellulose. The hydrolysis of cellulose to cellobiose is the rate-limiting step, and this limitation is resolved by cellobiohydrolases which hydrolyse cellulose to cellobiose and cellotriose. However, the small amount of $\beta$-glucosidase in cellulase hinders the cellulolysis process; hence, the addition of $\beta$-glucosidase helps cellulase to hydrolyse the intermediate product, cellobiose, to form glucose in a faster reaction time while minimizing product inhibition during the cellulolytic process [18-25]. Furthermore, the kinetics of molecular activation drawdown is faster in the double enzyme case 
and this favors forward production of fermentable subunits during the hydrolysis process. The total crystallinity index (TCI) of the hydrolyzed biomass was calculated as reported by Nelson and O'Connor [19]. From the calculations, the TCI of all the hydrolysed samples decreased when compared with the nonhydrolysed biomass. Decreasing biomass crystallinity has been reported to increase enzymatic hydrolysis rates [26]. Although the polysaccharides were degraded during hydrolysis, FTIR spectra analysis showed that the structure of the hydrolysed monomers remained intact for bioethanol production.

3.3. Glucose Yield. Table 2 shows the yield of glucose for different assays. The rate of glucose release was rapid at the beginning of hydrolysis and slowed down until the end of the hydrolysis process. This profile is typical of batch hydrolysis [9]. Note that the enzymes involved in the study are not hydrolysing starch composition thus not accounted for potential glucose for the fermentation process. It was found that biomass with smaller particle size generated higher glucose yields and this observation was the same for both Case 1 and Case 2 . The highest glucose yields were $75.45 \mathrm{mg} / \mathrm{g}$ biomass and $134.73 \mathrm{mg} / \mathrm{g}$ biomass for Cases 1 and 2, respectively, for biomass in the smallest particle size range of $35 \mu \mathrm{m} \leq$ $x \leq 90 \mu \mathrm{m}$. The lowest glucose yields were $26.01 \mathrm{mg} / \mathrm{g}$ biomass and $61.55 \mathrm{mg} / \mathrm{g}$ biomass for Cases 1 and 2, respectively, for biomass in the largest particle size range of $295 \mu \mathrm{m} \leq x \leq$ $425 \mu \mathrm{m}$. Smaller biomass particle size increases the interactions with the enzymes during hydrolysis due to the presence of a large exposed surface area [12]. Hence, smaller microalgal biomass particle size is required to achieve higher glucose yield. The amount of microalgal biomass loaded in the hydrolysis process also showed a significant effect on glucose yields. Although the same microalgal biomass particle size was used in assay numbers 1,2 , and 3 , different glucose yields of $111.08 \mathrm{mg} / \mathrm{g}$ biomass, $125.77 \mathrm{mg} / \mathrm{g}$ biomass, and $134.73 \mathrm{mg} / \mathrm{g}$ biomass were achieved. When examining the effect of different substrate concentrations on glucose yield within the same particle size range in Case 2, it was found that the glucose yield increased with increasing substrate concentration. This trend was however not observed in Case 1 containing cellulose enzyme. Therefore, high yield of glucose from increasing substrate concentration is dependent on the balanced composition of cellulosic enzyme components to minimize product inhibition [27]. Furthermore, a significant increase in glucose yield was observed when the second enzyme (cellobiase) was introduced to the assays (Case 2). The glucose yields in Case 2 were almost the double compared to those obtained in Case 1. From the collision theory perspective, the kinetics of molecular activation drawdown is faster in the double enzyme case and this favors forward production of fermentable subunits. The kinetics of this double enzyme effect is demonstrated with the scheme below.

Mechanism of enzymatic hydrolysis of cellulase, Case 1:

$$
S+E \underset{k_{-1}}{\stackrel{k_{1}}{\rightleftarrows}} \mathrm{SE} \stackrel{k_{2}}{\longrightarrow} P+E,
$$

where $S$ is the substrate concentration, $E$ is the enzyme concentration, $\mathrm{SE}$ is the concentration of substrate-enzyme complex, $P$ is the product concentration, and $k_{1}, k_{-1}, k_{2}$ are rate constants.

The rates of change in SE concentration and product formation are

$$
\begin{gathered}
\frac{d \mathrm{SE}}{d t}=k_{1} S \times E-k_{-1} \mathrm{SE}-k_{2} \mathrm{SE}, \\
\frac{d P}{d t}=k_{2} \mathrm{SE} .
\end{gathered}
$$

For substrate mass balance, the substrate concentration $(S)$ is written as

$$
S=S_{o}-\mathrm{SE}-P
$$

Substituting (4) into (2) gives

$$
\frac{d \mathrm{SE}}{d t}=k_{1}\left(S_{0}-\mathrm{SE}-P\right) \times E-k_{-1} \mathrm{SE}-k_{2} \mathrm{SE} .
$$

Applying equilibrium and steady state conditions to (5) gives

$$
\mathrm{SE}=\frac{\left(S_{0}-P\right) E}{K_{e}+E},
$$

where $K_{e}$ is the equilibrium constant

$$
K_{e}=\frac{k_{-1}+k_{2}}{k_{1}} .
$$

The simplified equation (6) may be written as follows at initial conditions:

$$
\left(\frac{d P}{d t}\right)_{P_{0}}=\frac{k_{2} S_{0} E_{0}}{K_{e}+E_{0}},
$$

where $(d P / d t)_{P_{0}}$ denotes the product formation at the initial conditions.

The mechanism of the enzymatic hydrolysis of cellulase $\left(E_{1}\right)$ and cellobiase $\left(E_{2}\right)$, Case 2 , is

$$
\begin{gathered}
S_{\mathrm{C}}+E_{1} \underset{k_{-1}}{\stackrel{k_{1}}{\rightleftarrows}} S_{\mathrm{C}} E_{1} \stackrel{k_{2}}{\longrightarrow} S_{\mathrm{CB}}+E_{1}, \\
S_{\mathrm{CB}}+E_{2} \underset{k_{-1}^{\prime}}{\stackrel{k_{1}^{\prime}}{\rightleftarrows}} S_{\mathrm{CB}} E_{2} \stackrel{k_{2}^{\prime}}{\longrightarrow} P+E_{2},
\end{gathered}
$$

where $S_{C}, S_{\mathrm{CB}}$, and $P$ are concentrations of cellulose, cellobiose, and glucose, respectively.

By following the same procedure as in Case 1, simplified equation for Case 2 at the initial conditions is

$$
\begin{gathered}
\left(\frac{d P}{d t}\right)_{P_{0}}=\frac{k_{2}^{\prime} E_{2}\left(S_{C_{0}}-S_{C} E_{1_{0}}-S_{C B_{0}}\right)}{K_{e}^{\prime}+E_{2_{0}}}, \\
K_{e}^{\prime}=\frac{k_{2}^{\prime}+k_{-1}^{\prime}}{k_{1}^{\prime}},
\end{gathered}
$$


TABLE 2: Yield of glucose released after $48 \mathrm{~h}$ of hydrolysis.

\begin{tabular}{lcccc}
\hline Assay number & Particle size, $\mu \mathrm{m}$ & Algae loading, g/L & Cellulase (Case 1) & mg glucose/g algal biomass \\
Cellulase + cellobiase (Case 2)
\end{tabular}

where $k_{1}^{\prime}, k_{-1}^{\prime}$, and $k_{2}^{\prime}$ are rate constants and $K_{e}^{\prime}$ is the equilibrium constant.

Equations (8) and (10) can be rewritten as follows.

For Case 1,

$$
\frac{1}{v}=\frac{K_{e}}{V_{0}}\left[\frac{1}{S_{o}}\right]+\frac{1}{V_{0}},
$$

where

$$
V_{0}=k_{2} E
$$

For Case 2,

$$
\frac{1}{v}=\frac{K_{e}^{\prime}}{V_{0}^{\prime}}\left[\frac{1}{S_{\mathrm{CB}}}\right]+\frac{1}{V_{0}^{\prime}},
$$

where

$$
V_{0}^{\prime}=k_{2}^{\prime}\left(E_{T}-S_{C} E_{1}\right)
$$

From the mathematical derivation, $K_{m}$ which is the equilibrium constant is $K_{e}$ for Case 1 and $K_{e}^{\prime}$ for Case 2. Also, $V_{\max }$ which is the maximum forward velocity is $1 / V_{0}$ for Case 1 and $1 / V_{0}^{\prime}$ for Case 2, where $V_{0}$ and $V_{0}^{\prime}$ occur at their respective initial enzyme concentration. As can be seen in Table 3, Lineweaver-Burk plot analysis of (12) and (14) shows that the $K_{m}$ value for Case 1 is higher than Case 2 and the $V_{\max }$ value for Case 1 is lower than Case 2. The lower value of $K_{m}$ and the higher value of $V_{\max }$ obtained from Case 2 confirm that the introduction of cellobiase significantly increases the combined enzyme-substrate affinity and the hydrolysis rate.

3.4. Ethanol Yield. The produced hydrolysates were used as substrates in Saccharomyces cerevisiae fermentations for bioethanol production. This yeast strain has widely been utilized for bioethanol production because it is easy to culture and has a high ethanol tolerance. This could allow fermentation to continue under $16-17 \%$ v/v ethanol concentrations [28]. Figure 2 shows the bioethanol yields for both Cases 1 and 2 using biomass with different particle sizes. The trend in bioethanol yield for the different particle size biomass was in agreement with the glucose yields;
TABLE 3: $K_{m}$ and $V_{\max }$ for hydrolysis of cellulose by cellulase (Case 1) and cellulase + cellobiase (Case 2).

\begin{tabular}{lccc}
\hline \multirow{2}{*}{ Case number } & \multirow{2}{*}{ Enzyme } & \multicolumn{2}{c}{ Hydrolysis of cellulose } \\
& & $K_{m}$ & $V_{\max }$ \\
\hline 1 & Cellulase & 18.81 & 35.05 \\
2 & Cellulase + cellobiase & 18.23 & 135.83 \\
\hline
\end{tabular}

biomass with smaller particle size displayed higher glucose concentrations to generate higher bioethanol yields. It can be observed that available glucose in the hydrolysate was completely consumed after $48 \mathrm{~h}$ of fermentation. The highest bioethanol yield of $0.47 \mathrm{~g}$ ethanol $/ \mathrm{g}$ glucose was obtained when hydrolysed under Case 2 with the smallest particle size biomass $(35 \mu \mathrm{m} \leq x \leq 90 \mu \mathrm{m})$ at $100 \mathrm{~g} / \mathrm{L}$ microalgae concentration, whereas the lowest bioethanol yield of $0.05 \mathrm{~g}$ ethanol/g glucose was obtained when hydrolysed under Case 1 with the largest particle size biomass $(295 \mu \mathrm{m} \leq x \leq 425 \mu \mathrm{m})$ at $25 \mathrm{~g} / \mathrm{L}$ microalgae concentration. Assays in Case 2 produced up to $50 \%$ more bioethanol yields than the assays in Case 1 , reaching a maximum bioethanol yield of $0.47 \mathrm{~g} / \mathrm{g}$ glucose compared to $0.19 \mathrm{~g} / \mathrm{g}$ glucose, as represented by assay number 3 in both cases. Hydrolysate produced in the presence of cellobiase generated higher bioethanol yields due to the presence of high glucose concentrations.

3.5. Viscosity Analysis. The purpose of the viscosity study is to understand the influence of the rheological properties of the hydrolysate during hydrolysis and how this affects the fermentation process for bioethanol production. The viscosity measurements were performed under different shear rates (50-500 $\mathrm{s}^{-1}$ ) using hydrolysates obtained from biomass with different particle sizes for an equivalent substrate concentration of $100 \mathrm{~g} / \mathrm{L}$. Figure 3 shows the viscosity data of the different particle size biomass for both Cases 1 and 2 with samples taken after the hydrolysis process. A decreasing trend of viscosity was observed with increasing shear rate and biomass with smaller particle sizes displaying higher viscosities. For biomass in the same particle size range, Case 2 showed 


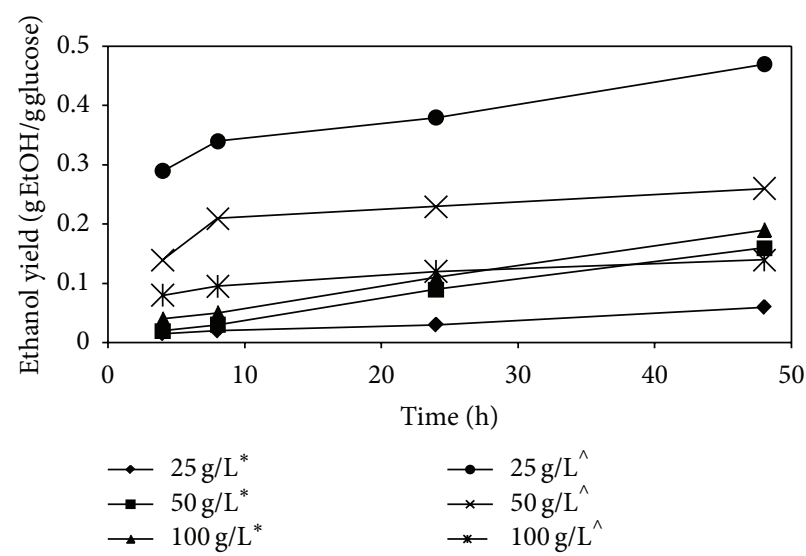

(a)

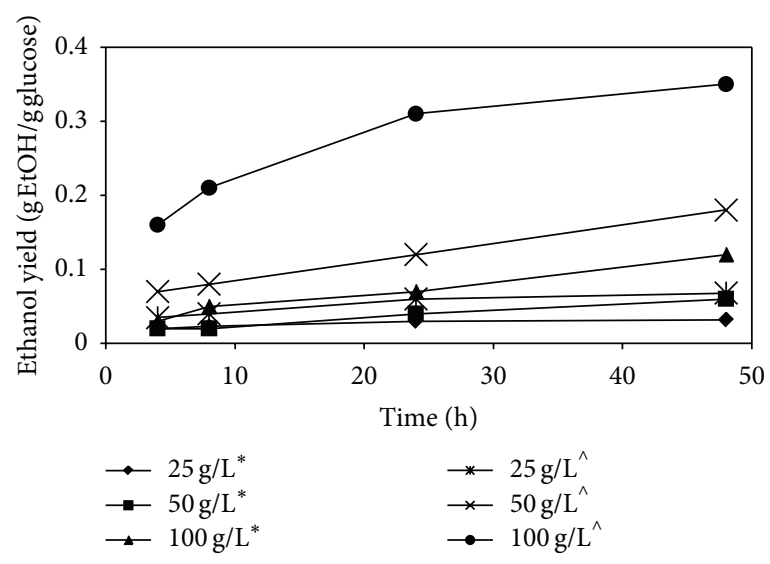

(b)

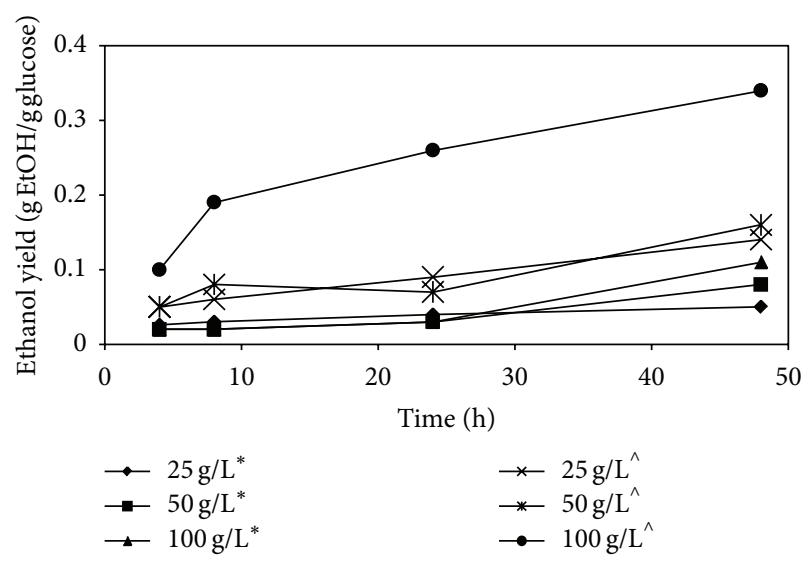

(c)

FIGURE 2: Yield of bioethanol after $48 \mathrm{~h}$ fermentation of microalgal biomass with different particle sizes for both cases: (a) $35 \mu \mathrm{m} \leq x \leq 90 \mu \mathrm{m}$, (b) $125 \mu \mathrm{m} \leq x \leq 180 \mu \mathrm{m}$, and (c) $295 \mu \mathrm{m} \leq x \leq 425 \mu \mathrm{m}\left({ }^{*}\right.$ Case 1: cellulase; ${ }^{\wedge}$ Case 2 : cellulase + cellobiase).

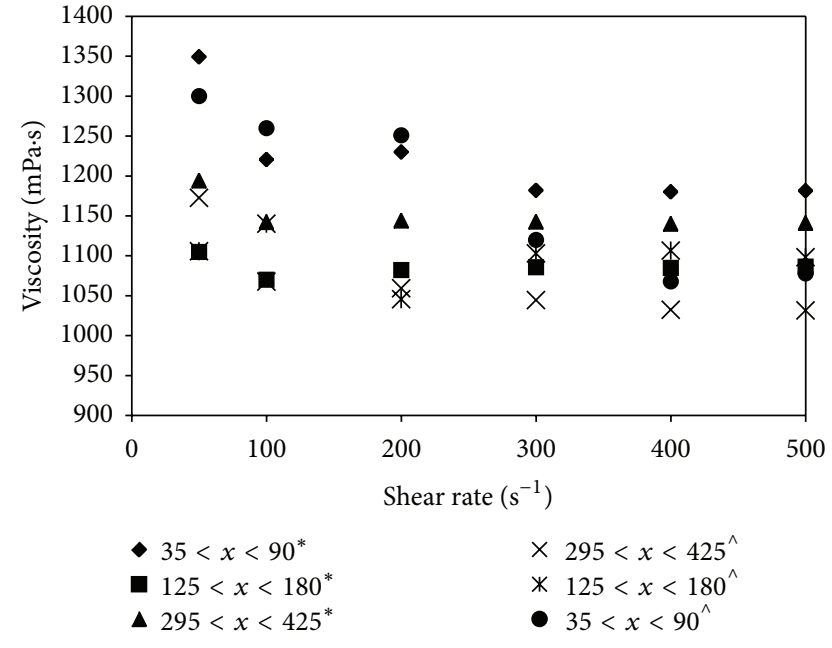

Figure 3: Viscosity versus shear rate for the different particle size biomass. A decreasing trend in viscosity was observed with increasing shear rate $\left({ }^{*}\right.$ Case 1 : cellulase; ${ }^{\wedge}$ Case 2 : cellulase + cellobiase; substrate concentration: $100 \mathrm{~g} / \mathrm{L}$ ). a slightly higher viscosity than Case 1 . The effective enzymesubstrate interactions associated with smaller particle size biomass result in a more viscous hydrolysate than large size particles as more water molecules are consumed per unit volume, exceeding the reduction of total solids concentration [29].

We also studied the viscosity profile of the hydrolysates over the time course of hydrolysis and the data is presented in Figure 4. The hydrolysate viscosities for both Cases 1 and 2 reduced with hydrolysis time with a significant decrease which was observed at the initial stage of hydrolysis between 4 and $24 \mathrm{~h}$. This is probably due to the faster initial kinetics, structural changes, and/or the release of intercalating molecules in the cell wall. Decreasing viscosity during hydrolysis is caused by cellulose degradation as the structure and solid concentration change during the cellulolytic activity caused by the enzymes [10].

The profiles of viscosity and bioethanol production were superimposed to understand their relationship during the enzymatic hydrolysis process as shown in Figure 5. It can be seen that bioethanol yield increases with lower viscosities. 


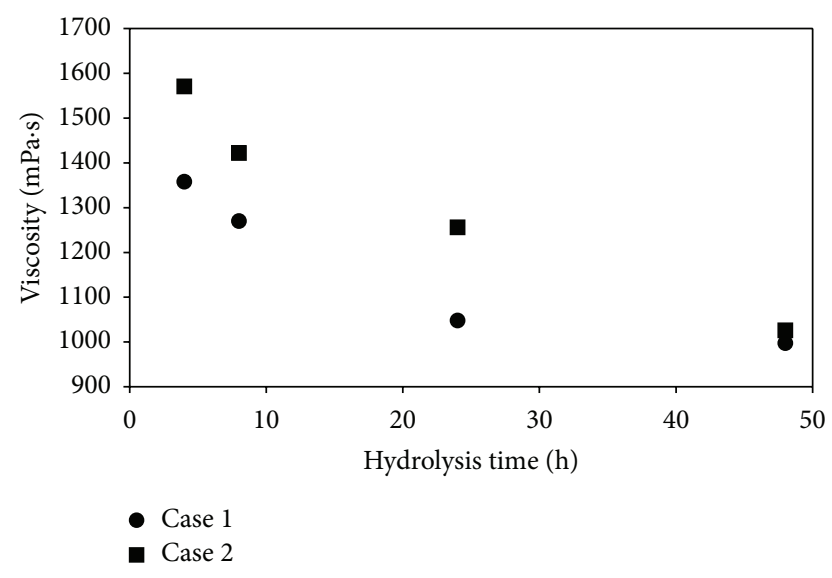

FIGURE 4: Hydrolysate viscosity profiles during hydrolysis for singleenzyme (Case 1: cellulase) and double-enzyme (Case 2: cellulase + cellobiase) conditions. The viscosity of the hydrolysates in both cases decreased with hydrolysis time. The data presented is for assay number 1 in both cases (substrate concentration: $25 \mathrm{~g} / \mathrm{L}$ ).

This trend also matches glucose yields as higher released glucose produces higher bioethanol yields. The results show that less viscous slurry is required to produce high glucose yields under effective mixing.

\section{Conclusion}

This paper is the premier study on the effect of particle size of microalgal biomass on enzymatic hydrolysis and bioethanol production. The results show that the highest glucose and bioethanol yields were obtained using biomass with smaller particle size $(35 \mu \mathrm{m} \leq x \leq 90 \mu \mathrm{m})$ at a substrate concentration of $100 \mathrm{~g} / \mathrm{L}$. The addition of the second enzyme, cellobiase, increases the glucose yield, thus increasing the bioethanol yield. This was confirmed by a kinetic investigation of the double enzyme process using the rapid equilibrium model. The viscosity of the hydrolysate also influences glucose yield. Lower viscosities result in higher glucose yields. Overall, microalgal biomass particle size has a significant effect on enzymatic hydrolysis and bioethanol production.

\section{Abbreviations}

$\begin{array}{ll}S: & \text { Substrate concentration, g/L } \\ E: & \text { Enzyme concentration, g/L } \\ \text { SE: } & \text { Concentration of } \\ & \text { substrate-enzyme complex } \\ P: & \text { Product concentration, g/L } \\ k_{1}, k_{-1}, k_{2}, k_{1}^{\prime}, k_{-1}^{\prime}, \text { and } k_{2}^{\prime}: & \text { Rate constants, g/L } \\ K_{e}, K_{e}^{\prime}: & \text { Equilibrium constant, g/L } \\ (d P / d t)_{P_{0}}: & \text { Product formation at the } \\ & \text { initial conditions } \\ E_{1}: & \text { Enzyme I (cellulase) } \\ & \text { concentration, g/L } \\ E_{2}: & \text { Enzyme II (cellobiase) } \\ & \text { concentration, g/L }\end{array}$

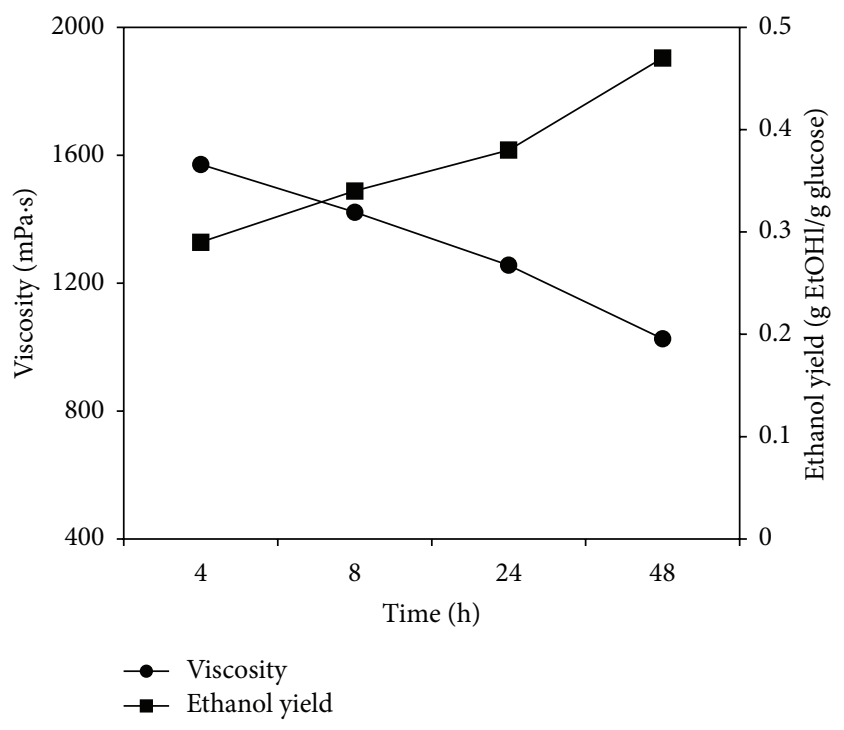

FIGURE 5: Relationship between hydrolysate viscosity and bioethanol yield. Bioethanol yield increases with lower hydrolysate viscosities. The data presented is for assay number 1 of Case 2 (substrate concentration: $25 \mathrm{~g} / \mathrm{L}$ ).

$S_{C}: \quad$ Cellulose concentration, $\mathrm{g} / \mathrm{L}$

$S_{\mathrm{CB}}: \quad$ Cellobiose concentration, $\mathrm{g} / \mathrm{L}$

$S_{C} E_{1}$ : Concentration of cellulose-cellulase complex

$S_{\mathrm{CB}} E_{2}$ : Concentration of cellobiose-cellobiase complex

$K_{m}: \quad$ Michaelis constant, g/L

$V_{\text {max }}:$ Maximum rate of hydrolysis, $\mathrm{g} / \mathrm{L} \cdot \mathrm{min}$.

\section{Conflict of Interests}

The authors declare that there is no conflict of interests regarding the publication of this paper.

\section{Acknowledgments}

This work has been supported by the Department of Chemical Engineering, Monash University, Australia, and the Ministry of Higher Education, Malaysia.

\section{References}

[1] R. Harun, M. Singh, G. M. Forde, and M. K. Danquah, "Bioprocess engineering of microalgae to produce a variety of consumer products," Renewable and Sustainable Energy Reviews, vol. 14, no. 3, pp. 1037-1047, 2010.

[2] V. K. Dhargalkar and X. N. Verlecar, "Southern Ocean seaweeds: a resource for exploration in food and drugs," Aquaculture, vol. 287, no. 3-4, pp. 229-242, 2009.

[3] J. L. Fortman, S. Chhabra, A. Mukhopadhyay et al., "Biofuel alternatives to ethanol: pumping the microbial well," Trends in Biotechnology, vol. 26, no. 7, pp. 375-381, 2008.

[4] S. P. Choi, M. T. Nguyen, and S. J. Sim, "Enzymatic pretreatment of Chlamydomonas reinhardtii biomass for ethanol production," Bioresource Technology, vol. 101, no. 14, pp. 5330-5336, 2010. 
[5] R. Harun, M. K. Danquah, and G. M. Forde, "Microalgal biomass as a fermentation feedstock for bioethanol production," Journal of Chemical Technology and Biotechnology, vol. 85, no. 2, pp. 199-203, 2010.

[6] Y. Zheng, Z. Pan, R. Zhang, and B. M. Jenkins, "Kinetic modeling for enzymatic hydrolysis of pretreated creeping wild ryegrass," Biotechnology and Bioengineering, vol. 102, no. 6, pp. 1558-1569, 2009.

[7] Y. Sun and J. J. Cheng, "Dilute acid pretreatment of rye straw and bermudagrass for ethanol production," Bioresource Technology, vol. 96, no. 14, pp. 1599-1606, 2005.

[8] L. T. Fan, Y. H. Lee, and D. H. Beardmore, "Mechanism of the enzymatic hydrolysis of cellulose: effects of major structural features of cellulose on enzymatic hydrolysis," Biotechnology and Bioengineering, vol. 22, pp. 177-199, 1980.

[9] M. Pedersen and A. S. Meyer, "Influence of substrate particle size and wet oxidation on physical surface structures and enzymatic hydrolysis of wheat straw," Biotechnology Progress, vol. 25, no. 2, pp. 399-408, 2009.

[10] R. K. Dasari and R. Eric Berson, "The effect of particle size on hydrolysis reaction rates and rheological properties in cellulosic slurries," Applied Biochemistry and Biotechnology, vol. 137-140, no. 1-12, pp. 289-299, 2007.

[11] L. M. J. Carvalho, R. Borchetta, and É. M. M. da Silva, "Effect of enzymatic hydrolysis on particle size reduction in lemon juice (Citrus limon, L.)," Brazilian Journal of Food Technology, vol. 4, pp. 277-282, 2006.

[12] A.-I. Yeh, Y.-C. Huang, and S. H. Chen, "Effect of particle size on the rate of enzymatic hydrolysis of cellulose," Carbohydrate Polymers, vol. 79, no. 1, pp. 192-199, 2010.

[13] I. Ballesteros, J. M. Oliva, A. A. Navarro, A. González, J. Carrasco, and M. Ballesteros, "Effect of chip size on steam explosion pretreatment of softwood," Applied Biochemistry and Biotechnology A: Enzyme Engineering and Biotechnology, vol. 84-86, pp. 97-110, 2000.

[14] I. Ballesteros, J. M. Oliva, M. J. Negro, P. Manzanares, and M. Ballesteros, "Enzymic hydrolysis of steam exploded herbaceous agricultural waste (Brassica carinata) at different particule sizes," Process Biochemistry, vol. 38, no. 2, pp. 187-192, 2002.

[15] B. Baldan, P. Andolfo, L. Navazio, C. Tolomio, and P. Mariani, "Cellulose in algal cell wall: an "in situ" localization," European Journal of Histochemistry, vol. 45, no. 1, pp. 51-56, 2001.

[16] K. Sander and G. S. Murthy, "Enzymatic degradation of microalgal cell walls," in Proceedings of the American Society of Agricultural and Biological Engineers Annual International Meeting, pp. 2489-2500, Reno, Nev, USA, June 2009.

[17] J. N. Murdock and D. L. Wetzel, "FT-IR microspectroscopy enhances biological and ecological analysis of algae," Applied Spectroscopy Reviews, vol. 44, no. 4, pp. 335-361, 2009.

[18] D. S. Domozych, M. Ciancia, J. U. Fangel, M. D. Mikkelsen, P. Ulvskov, and W. G. Willats, "The cell walls of green algae: a journey through evolution and diversity," Frontiers in Plant Science, vol. 3, article 82, 2012.

[19] M. L. Nelson and R. T. O’Connor, "Relation of certain infrared bands to cellulose crystallinity and crystal latticed type. Part I. Spectra of lattice types I, II, III and of amorphous cellulose," Journal of Applied Polymer Science, vol. 8, pp. 1311-1324, 1964.

[20] R. Sposina Sobral Teixeira, A. Sant'Ana da Silva, H.-W. Kim et al., "Use of cellobiohydrolase-free cellulase blends for the hydrolysis of microcrystalline cellulose and sugarcane bagasse pretreated by either ball milling or ionic liquid [Emim][Ac]," Bioresource Technology, vol. 149, pp. 551-555, 2013.

[21] C. Divne, J. Ståhlberg, T. Reinikainen et al., "The three-dimensional crystal structure of the catalytic core of cellobiohydrolase I from Trichoderma reesei," Science, vol. 265, no. 5171, pp. 524528, 1994.

[22] Y.-S. Liu, J. O. Baker, Y. Zeng, M. E. Himmel, T. Haas, and S.Y. Ding, "Cellobiohydrolase hydrolyzes crystalline cellulose on hydrophobic faces," Journal of Biological Chemistry, vol. 286, no. 13, pp. 11195-11201, 2011.

[23] J. Jalak and P. Väljamäe, "Mechanism of initial rapid rate retardation in cellobiohydrolase catalyzed cellulose hydrolysis," Biotechnology and Bioengineering, vol. 106, no. 6, pp. 871-883, 2010.

[24] S. Al-Zuhair, "The effect of crystallinity of cellulose on the rate of reducing sugars production by heterogeneous enzymatic hydrolysis," Bioresource Technology, vol. 99, no. 10, pp. 40784085, 2008.

[25] M. Chauve, H. Mathis, D. Huc, D. Casanave, F. Monot, and N. L. Ferreira, "Comparative kinetic analysis of two fungal $\beta$ glucosidases," Biotechnology for Biofuels, vol. 3, article 3, 2010.

[26] L. Liu and H. Chen, "Enzymatic hydrolysis of cellulose materials treated with ionic liquid [BMIM]Cl," Chinese Science Bulletin, vol. 51, no. 20, pp. 2432-2436, 2006.

[27] Q. Gan, S. J. Allen, and G. Taylor, "Kinetic dynamics in heterogeneous enzymatic hydrolysis of cellulose: an overview, an experimental study and mathematical modelling," Process Biochemistry, vol. 38, no. 7, pp. 1003-1018, 2003.

[28] G. P. Casey and W. M. Ingledew, "Ethanol tolerance in yeasts," Critical Reviews in Microbiology, vol. 13, no. 3, pp. 219-280, 1986.

[29] K. W. Dunaway, R. K. Dasari, N. G. Bennett, and R. Eric Berson, "Characterization of changes in viscosity and insoluble solids content during enzymatic saccharification of pretreated corn stover slurries," Bioresource Technology, vol. 101, no. 10, pp. 3575$3582,2010$. 

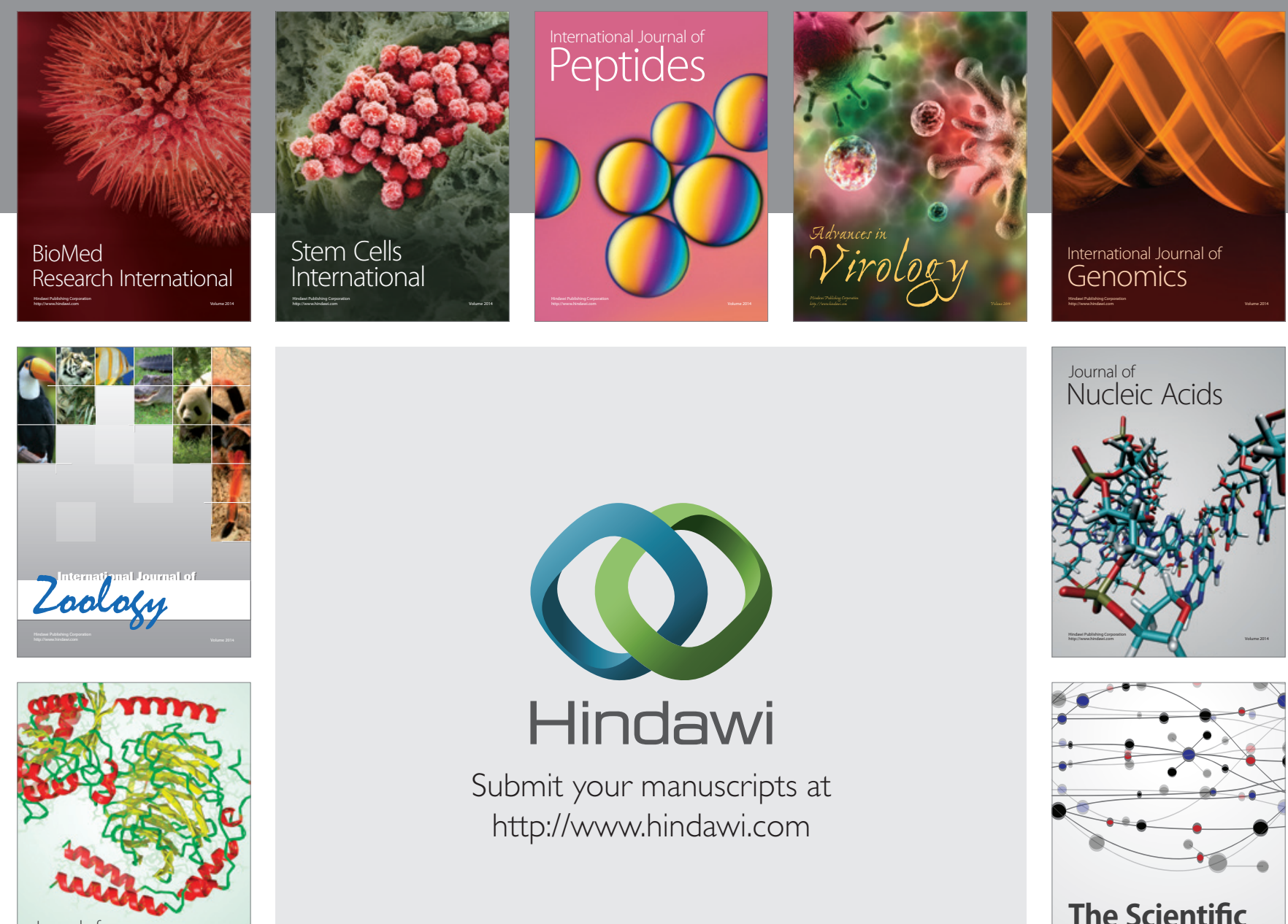

Submit your manuscripts at

http://www.hindawi.com

Journal of
Signal Transduction
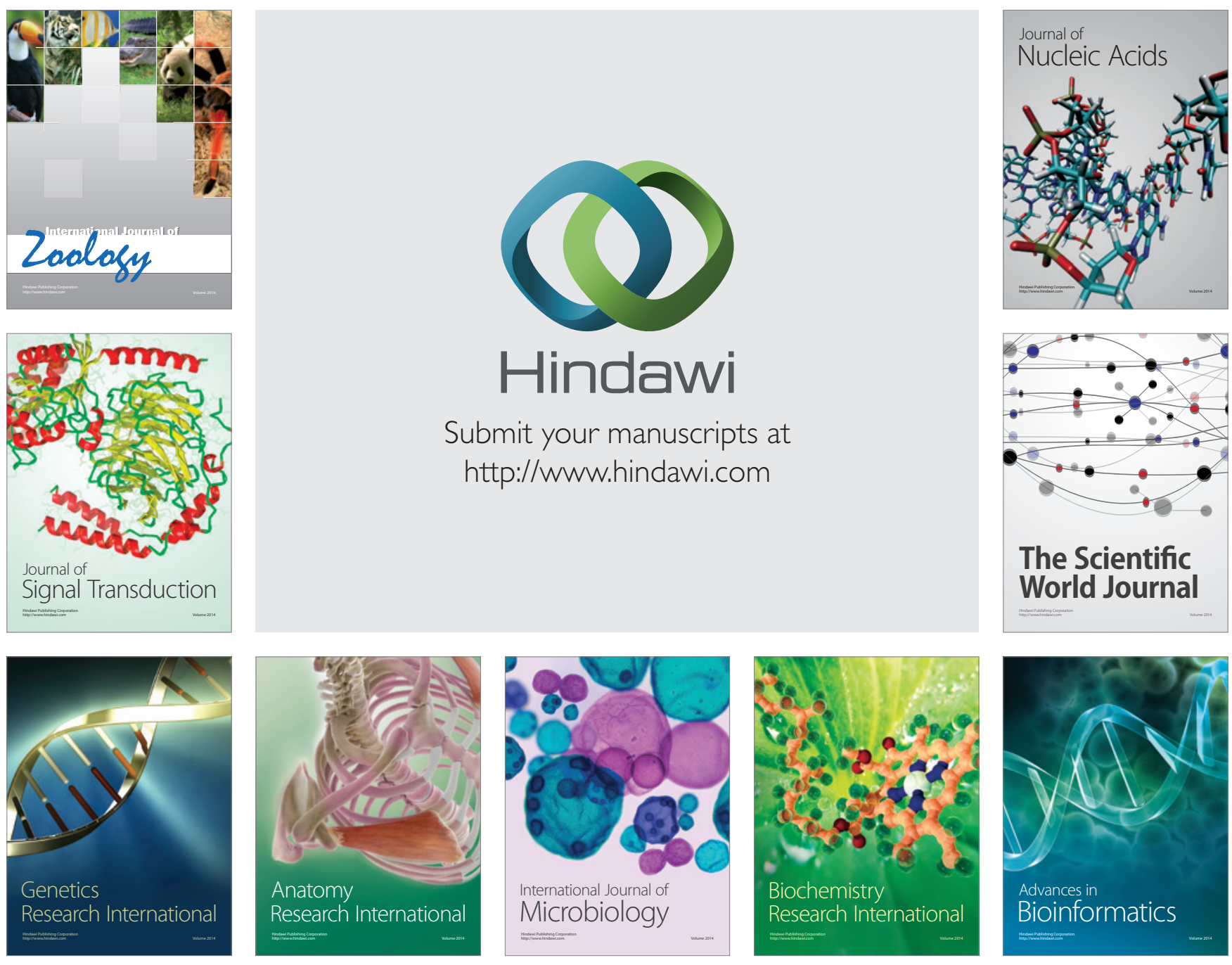

The Scientific World Journal
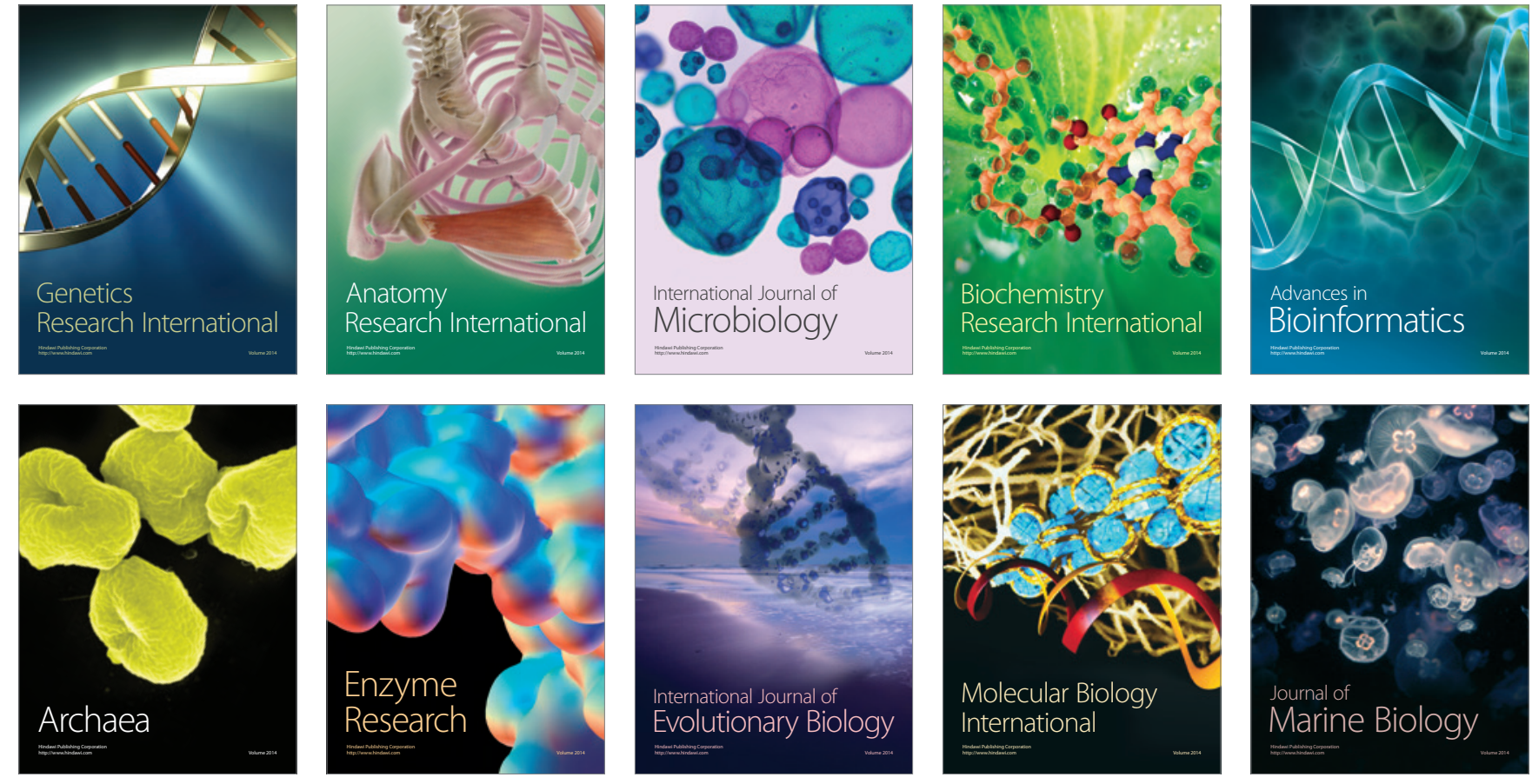